\title{
THE EFFECT OF INTERVENTION PROGRAMS ON HOW TO WORK COMPLAINTS IN MECHANICAL WORKERS IN HEAVY EQUIPMENT COMPANIES
}

\author{
Muhammad Ilyas ${ }^{1,3}$, Muhammad Soffiudin², Nuri Purwito Adi ${ }^{1,3}$, Astrid Sulistomo1, Aria Kekalih ${ }^{1,3}$ \\ ${ }^{1}$ Departement of Community Medicine, Faculty of Medicine Universitas Indonesia, Indonesia \\ ${ }^{2}$ Magister of Occupational Medicine, Faculty of Medicine Universitas Indonesia, Indonesia \\ ${ }^{3}$ Occupational Environmental Health and Research Center IMERI FKUI, Indonesia \\ Corespondence Address: Muhammad Ilyas \\ Email muhammadilyas@ui.ac.id
}

\begin{abstract}
Low back pain (LBP) is experienced by almost everyone during his life, and data in Indonesia ranged from 3-17\% based on hospital records. LBP can occur due to awkward body postures and manual handling during working and need intervention to reduce complaints. This study to know intervention to reduce risk at ergonomic can induce LBP. This study uses a quasi-experimental design using control with a sample of 35 in each group. The intervention program monitoring was carried out by the SHE team at the work site based on conducting weekly observations regarding workers doing awkward work postures and manual handling activities and ensuring that mechanical workers receive ergonomics training. After one year of the intervention program, the data collection was carried out using a questionnaire to find out the changes in the length of the squat position, bending position, and manual handling activities in both groups. Significant differences between the two groups were obtained in the long work category with squat posture with $\mathrm{p}$-value $<0,001$, bent posture with $\mathrm{p}$-value 0.001 , and a nonsignificant difference were found in the manual handling category with a p-value of 0.614 . The intervention program can change manual handling in the intervention group 3.6 times at work duration more than 1 hour in a squatting position and decrease in the length of bending position more 1 hour by 1.4 times compared to control.
\end{abstract}

Keywords: ergonomic training, squatting position, bending position, manual handling.

\section{INTRODUCTION}

According to (Ministry of Health Republic of Indonesia, 2016) Occupational diseases are artificial diseases because they arise caused by human work. Progress in the industry has brought convenience to human life, however, there are still problems in the world of work that cannot be overcome by existing technology, so that interaction between workers and the environment and work tools can harm workers. One form of interference that can arise due to work is low back pain (LBP). Low back pain is a clinical syndrome characterized by the main symptoms of pain or other feelings that are uncomfortable in the lower back region. More than $70 \%$ of human beings have experienced LBP in their lives, with an average peak age of 35-55 years. Meanwhile, (Suma'mur, 2009) LBP is a pain in the back area between the lower angle of the rib to the lumbosacral. Pain can also spread to other areas such as the upper back and groin.

Ergonomic study results at PT $\mathrm{X}$ in 2018 found $61 \%$ of mechanical workers were at risk of low back pain (LBP), working in a squatting position more than one hour/day, $49 \%$ working in a bent position more than one hour/day and 39\% lifting heavy objects manually (manual handling) more than $20 \mathrm{~kg}$.

Analyze the level of ergonomic risk for manual handling activities using the Quick Exposure Check (QEC) tool by (Li and Buckle, 1998). obtained 59.6\% of mechanical workers have a moderate to very high-risk level. Based on the overall data, $59 \%$ of mechanical workers have reported complaints of low back pain. The parts of the body that were most complained about related to 
musculoskeletal disorders (MSDs) during the last 7 days and 12 months showed that the highest prevalence of MSDs was found in the lower back.

In addition, efforts are made to diagnose occupational diseases by occupational specialists by ( Directorate of Occupational Health and Sports, Ministry of Health of the Republic of Indonesia, 2018) and (Morris, 2013). This effort consists of seven steps of examination to assess whether the low back pain experienced by employees can be classified as work-related or not. The total number of employees who were physically examined by doctors was 253 people. Based on the results of the examination, 18 mechanical workers were diagnosed positive for LBP.

Based on these data, there were many complaints of low back pain suffered by mechanical workers, researchers assisted by an internal team at PT X took several corrective actions in the form of implementing intervention programs such as health promotion through the installation of low back pain awareness posters at the worksites of the intervention and control groups. At the work location, PT X internal team conducted other interventions towards the intervention group, namely education in the form of ergonomics training, stretching, and regular exercise in the workplace. This study was conducted to determine whether there was a change in working methods and a decrease in complaints of low back pain in mechanic workers after intervention in the intervention group and the control group.

\section{METHOD}

The design of this research was quasi-experimental. The study was conducted by comparing changes in complaints of low back pain in mechanical workers, namely between work locations that received an intervention program to change the way of working in the form of education with the installation of posters with low back pain awareness as control with work locations that received additional work change intervention programs in the form of ergonomic training, stretching muscle and regular exercise at work with a ratio of 1:1, namely 35 samples as a control group and 35 samples as the intervention group.

Prior to the study, researchers collected and analyzed secondary data from the results of the 2018 ergonomics study related to the prevalence of mechanical workers with LBP complaints in the locations carried out in the study, namely Samarinda, Tanjung Tabalong, and BSD Tangerang, after getting enough secondary data the researchers coordinated with management in Samarinda. as the location for the intervention and management group in Tanjong Tabalong and BSD Tangerang as the location for the control group either by telephone or by direct visit to the location. During the research, the researcher collected primary data through interviews with 70 research subjects using technology media in the form of Microsoft Team, WhatsApp, and Telephone applications because of the Covid-19 pandemic. Researchers also made visits every 4 months to the location of the intervention group to monitor the implementation of intervention programs in the workplace to ensure that intervention programs in the form of LBP awareness posters, ergonomics training, muscle stretching, and exercise were carried out regularly.

The method of selecting samples using convenience sampling technique where mechanical workers at heavy equipment company carried out an educational program in the form of health promotion through the installation of low back pain awareness posters, namely work location A from 23 samples selected 17 mechanical workers who participated in interviews in previous research and work location B from The 21 samples were selected as many as 18 mechanical workers who attended interviews in the previous 
study. The location was chosen because it is the baseline research location.

In the intervention group, ergonomics training was carried out once a year and the installation of LBP prevention posters to change the way of working by avoiding hunchbacked squatting and lifting weights $>20 \mathrm{~kg}$ manually, stretching muscles 1x / day, and exercising once per month while in the control group only installing posters for the prevention of LBP. Ergonomics training was carried out directly by researchers assisted by Health Safety and Environmental (HSE) officers at worksites referring to the training syllabus, the making of LBP prevention posters was assisted by the Corporate Communication Department, and poster installation was carried out by HSE personnel at work sites, the muscle stretching method refers to the Machliss (2011). This muscle stretching is led by mechanic workers in turn and exercisers are led by an external professional instructor. Measurement of changes in working methods and complaints of LBP in both groups using a questionnaire. Ergonomics training is carried out directly by researchers assisted by HSE officers at worksites refer to the training syllabus matrix, LBP prevention poster postings are carried out by HSE personnel at work sites. Measurement of changes on how to work and LBP complaints in both groups using a questionnaire after one year intervention program.

Data processing was performed using the SPSS 20.0 program (Landau Sabine, 2001),(Bertani et al., 2018). The data obtained will be entered into a computer and then analyzed by univariate and bivariate. Univariate analysis was carried out to see the frequency distribution of all the variables studied, including individual characteristics and occupation. In the univariate test, normality was assessed using the Kolmogorov Smirnov test. The bivariate analysis aims to see the relationship of each variable. The p-value which was considered significant was
<0.05. The bivariate test used for categorical and categorical variable tests used Chi-Square or Fisher and for categorical and numeric variables tested by the Independent T-Test or Mann-Whitney test. The study protocol was approved by the ethics committee of the Faculty of Medicine, Universitas Indonesia (No: KET388/UN2.F1/ETIK/PPM.00.02/2020).

\section{RESULT}

Mechanical workers by their assignments can be assigned to Heavy Equipment company's work location in a workshop or at a customer location in the field (field), assignments are carried out randomly according to operational needs. General working hours for mechanic workers in workshops are from 08.00 17.00 with 3 breaks from 10.00 - 10.15, 12.00 - 13.00 and 15.00 - 15.30 from Monday - Friday, while for mechanic workers in the field they follow customer work times well with shifts or without shift. Work shifts are divided into two shifts, namely morning shifts from $08.00-17.00$ and night shifts from $20.00-05.00$ hours with the same three break times for nonshift workers with five working days a week.

The workflow starts in the morning by conducting a toolbox meeting to discuss the work to be done at that time, the division of work, including ensuring that work is carried out with attention to the safety and health aspects of work. The job description of mechanical workers is generally divided into four, there are remove or install various components from or to the heavy equipment unit by the procedure, performing assembly and disassembly of various components of the machine according to the procedure, carry out maintenance activities of various types of heavy equipment units and machines and inspect and report using standard forms

After completing the toolbox meeting, each mechanical worker will prepare the necessary work equipment, 
review the service manual for the type of work to be performed and review the Job safety assessment (JSA) to ensure the HSE aspects that need to be considered during the work process. After that, mechanical workers begin to carry out work processes according to the type of work assigned by their supervisor or foreman. Thirty minutes before the work time is over, mechanical workers stop doing the work process to tidy up the workplace and return work equipment to the counter.
The length of the work process required varies depending on the type of work being done. The fastest duration is one day for inspection, reporting using standard forms, and a maximum duration of six months for assembling and disassembling various engine components. Work was carried out continuously, for work that has not been completed will be resumed on the next day.

The results of the analysis of preintervention data in the age category for the intervention and control groups:

Table 1. Characteristic Demographic of Workers

\begin{tabular}{|c|c|c|c|c|}
\hline Variable & $\begin{array}{c}\text { Intervention } \\
(\mathbf{n}=\mathbf{3 5}) \\
\mathbf{n}(\%)\end{array}$ & $\begin{array}{c}\text { Control } \\
(n=35) \\
n(\%)\end{array}$ & Total & p Value \\
\hline Age (numeric) & $34.7(23-48)$ & $31.2(23-55)$ & 70 & $0.701^{1}$ \\
\hline \multicolumn{5}{|l|}{ Age (category) } \\
\hline$<35$ years old & $19(54.3)$ & $27(77.1)$ & 46 & $0.044^{\mathrm{cs}}$ \\
\hline$\geq 35$ years old & $16(45.7)$ & $8(22.9)$ & 24 & \\
\hline \multicolumn{5}{|l|}{ Years of Service } \\
\hline$<10$ years & $10(28.6)$ & $19(54.3)$ & 29 & $0.029^{\mathrm{cs}}$ \\
\hline Variable & $\begin{array}{c}\text { Intervention } \\
(\mathbf{n}=35) \\
\mathbf{n}(\%)\end{array}$ & $\begin{array}{c}\text { Control } \\
(n=35) \\
n(\%)\end{array}$ & Total & p-Value \\
\hline$\geq 10$ years & $25(71.4)$ & $16(45.7)$ & 41 & \\
\hline \multicolumn{5}{|c|}{$\begin{array}{l}\text { LBP complaints } \\
\text { (pre-intervention) }\end{array}$} \\
\hline Yes & $24(68.6)$ & $20(57.1)$ & 44 & $0.322^{\mathrm{cs}}$ \\
\hline No & $11(31.4)$ & 15 (42.9) & 26 & \\
\hline
\end{tabular}

cs) Chi square

1) levene

Most of the workers' age was less than 35 years old, in the category of years of service for the intervention group the most in the years of the service period of $\geq$ 10 years and for the control group the most in the years of service period less than 10 years, at low back pain complaints category for the intervention and control group at most there are low back pain complaints. The results of the equality test on the pre- intervention data show that the data are not homogeneous at age (category), work period, and homogeneous data at age (numeric) and LBP complaints. The age distribution in the intervention group was dominated by those over 35 years old (54.3\%) and had a work period of more than 10 years $(71.4 \%)$. In contrast to the control group, the age was younger $(77.1 \%)$ and the work period was under 10 years $(54.3 \%)$. 
Table 2. Changes in Occupational Risk Factors and LBP Complaints in the Intervention and Control Group

\begin{tabular}{|c|c|c|c|c|c|}
\hline Variable & $\begin{array}{l}\text { Intervention } \\
(\mathrm{n}=35) \\
\mathrm{n}(\%)\end{array}$ & $\begin{array}{l}\text { Control } \\
(\mathbf{n}=35) \\
n(\%)\end{array}$ & Total & p-Value & RR (CI 95\%) \\
\hline \multicolumn{6}{|l|}{$\begin{array}{l}\text { Length of work in } \\
\text { squatting position }\end{array}$} \\
\hline$\leq 1$ hour & $25(71.4)$ & $7(20)$ & 32 & $0.000^{\mathrm{cs}}$ & $\begin{array}{l}3.571(1.738 \\
-7.156)\end{array}$ \\
\hline$>1$ hour & $10(28.6)$ & $28(80)$ & 38 & & \\
\hline \multicolumn{6}{|l|}{$\begin{array}{l}\text { Length of work in } \\
\text { bending position }\end{array}$} \\
\hline$\leq 1$ hour & 31(88.6) & $22(62.9)$ & 53 & $0.012^{\mathrm{cs}}$ & $\begin{array}{l}1.409(1.064 \\
-1.866)\end{array}$ \\
\hline$>1$ hour & $4(11.4)$ & $13(37.1)$ & 17 & & \\
\hline \multicolumn{6}{|l|}{$\begin{array}{l}\text { Manual handling } \\
(\mathrm{kg})\end{array}$} \\
\hline$\leq 20 \mathrm{~kg}$ & $34(97.1)$ & $32(91.4)$ & 66 & $0.614^{\mathrm{fe}}$ & $\begin{array}{l}1.063(0.946 \\
-1.194)\end{array}$ \\
\hline$>20 \mathrm{~kg}$ & $1(2.9)$ & $3(8.6)$ & 4 & & \\
\hline \multicolumn{6}{|l|}{$\begin{array}{l}\text { Acute LBP } \\
\text { complaints (last } 7 \\
\text { days) }\end{array}$} \\
\hline Yes & $4(11.4)$ & $9(25.7)$ & 13 & $0.124^{\mathrm{cs}}$ & $\begin{array}{c}0.444(0.151 \\
-1.310)\end{array}$ \\
\hline No & 31 (88.6) & $26(74.3)$ & 57 & & \\
\hline \multicolumn{6}{|l|}{$\begin{array}{l}\text { Chronic LBP } \\
\text { complaints (last } 1 \\
\text { year) }\end{array}$} \\
\hline Yes & $16(45.7)$ & $28(80)$ & 44 & $0.003^{\mathrm{cs}}$ & $\begin{array}{c}0.571(0.384 \\
-0.850)\end{array}$ \\
\hline No & $19(54.3)$ & $7(20)$ & 26 & & \\
\hline \multicolumn{6}{|l|}{$\begin{array}{l}\text { Acute LBP } \\
\text { complaints (last } 7 \\
\text { days) }\end{array}$} \\
\hline Improve & $21(60)$ & $16(45.7)$ & 37 & $0.231^{\mathrm{cs}}$ & $\begin{array}{c}1.338(0.822 \\
-2.177)\end{array}$ \\
\hline Fixed/worsened & $14(40)$ & $19(54.3)$ & 33 & & \\
\hline
\end{tabular}




\begin{tabular}{lllcll}
\hline Variable & $\begin{array}{l}\text { Intervention } \\
(\mathbf{n = 3 5}) \\
\mathbf{n}(\boldsymbol{\%})\end{array}$ & $\begin{array}{l}\text { Control } \\
(\mathbf{n = 3 5}) \\
\mathbf{n}(\boldsymbol{\%})\end{array}$ & Total & p-Value & RR (CI 95\%) \\
\hline $\begin{array}{l}\text { Chronic LBP } \\
\text { complaints (last 1 } \\
\text { year) }\end{array}$ & & & & & \\
$\begin{array}{l}\text { Improve } \\
\text { Fixed/worsened }\end{array}$ & $26(74.3)$ & $31(88.6)$ & 57 & & \\
$\begin{array}{l}\text { cs) } \text { chi-square } \\
\text { fe) } \\
\text { fisher exact }\end{array}$ & & & & & \\
\end{tabular}

After the intervention, there were differences in results between the intervention group and the control group. In the intervention group, the habit of working in a squatting position was significantly reduced compared to the control group $(\mathrm{p}=$ $0.00)$. Likewise, the habit of working with a bent posture> 1 hour, obtained a significant difference between the intervention group and the control group, wherein for the intervention group the habit of working with a bent position was much less than the control group ( $p<0.01)$. (Bridger, 2018)

\section{DISCUSSION}

In the age category (categorical data) the results are not homogeneous while in the age category (numerical data) the results are homogeneous, in the years of service category the results are not homogeneous, and in the low back pain complaint category, the results are homogeneous. Based on these data this research was quite strong enough because it uses the same or homogeneous baseline data in the age category (numerical data) and LBP complaints. Research said LBP risk factors consisted of individual risk factors and occupational risk factors and also ergonomic risks (Sulaeman and Kunaefi, 2015). Jin said the most factor was overexertion in lifting and repetitive motion. (Jin et al., 2011) This study examines both of these factors using postintervention data where the individual factors of the researcher analyze the relationship of individual factors in the form of age, years of service, and smoking status with LBP complaints and for occupational risk factors the researcher analyses the relationship of occupational risk factors for length of work in squatting position, length of work in bending position and activity of lifting heavy objects $>20 \mathrm{~kg}$ (manual handling) manually with LBP complaints. This result is different from another research that stated a longer tenure can increase LBP complaints, as well as stated that increasing age can increase LBP complaints. (Rahayu, 2012), (Suma'mur, 2012)

This study also analyzed changes in occupational risk factors length of work in squatting position, length of work in bending position, and lifting activity $>20 \mathrm{~kg}$ in both groups for the intervention group and the control group. The results of data analysis in the category length of work in squatting position for the intervention and control group found a significant difference where the intervention can reduce the length of work in squatting position $>$ one hour by 3.6 times, in the length of work in bending position category there was a significant difference with the value $\mathrm{p} 0.012$ where the intervention can reduce the length of working bent position $>1$ hour by 1.4 times, in the category of manual handling for the intervention and control groups found no significant relationship, where the intervention was not proven to 
reduce the frequency of lifting heavy objects $>20 \mathrm{~kg}$.

The intervention program carried out was proven to be able to change on mechanics ways of working who previously worked with squatting and bending positions more than one hour to less than one hour, where there is a decrease in all three categories in the intervention group and two categories in the control group compared with the results of a study conducted at Heavy equipment company in 2018. The intervention group for a long working squat position more than one hour from $61 \%$ decreased to $28.6 \%$, while in the control group experienced an increase to $80 \%$ and in the intervention group for a long working bent position, more than one hour from $49 \%$ decreased to $11.4 \%$ while in the control group it decreased slightly to $37.1 \%$. Changes in how mechanics work can occur due to interventions carried out in the intervention group in the form of training on ergonomics and posting LBP awareness posters, while the control group only posted LBP awareness posters. During the four hour duration of training for mechanical workers, researchers included in the training syllabus refer to (Koh et al., 2017) who related to ergonomic risk factors which explain that working with awkward postures such as squatting and bending for a long time or $>1$ hour could increase the risk of LBP.

According to (Bridger, 2018) and (Li and Buckle, 1998) work with squat and bent postures will increase the burden on the back muscles and can cause the structure of the spine to be overloaded and increase the activity of the entire muscle causing an increased risk of spinal cord injury. This program intervention on how to work is referred to as the behavior changes strategy. (Week, 2016) there are four behavioral changes strategies namely using power, providing information, discussing participation, and action. The intervention program was carried out using a behavioral change strategy approach where the intervention was carried out by providing information through the posting of awareness posters about LBP as well as discussion of participation through ergonomics training conducted to mechanical workers on the dangers of working with squatting, bending, and lifting heavy objects more than $20 \mathrm{~kg}$.

There were changes in manual handling activities for lifting heavy objects manually more than $20 \mathrm{~kg}$ without tools in both groups, in the intervention group decreased from $39 \%$ to $2.9 \%$ while in the control group decreased to $8.6 \%$. This is good because lifting heavy objects $>20 \mathrm{~kg}$ manually is a risk factor for LBP, according to (Widanarko et al., 2015) and (Trippolini et al., 2018) where a heavy burden will cause irritation, inflammation, muscle fatigue, damage to muscles, tendons, and other tissues. Although in the intervention group there was a higher decrease there was no significant difference between the two groups, this could be since both groups already had a good knowledge of manual handling as in both groups information was provided through LBP awareness posters media to avoid lifting objects manually, other than that for the intervention group got more information from ergonomic training and the control group can get this from other sources such as health talks, etc.

The results of the data analysis on the proportion category of acute LBP complaints about the intervention and control groups showed a high decrease, namely in the intervention group from $68.6 \%$ to $11.4 \%$ and in the control group from $57.1 \%$ to $25.7 \%$, but significant in both groups found no significant difference with p-value 0.124 , where the intervention was not proven to reduce complaints of acute LBP. Referring to these results, the first hypothesis is not proven that the intervention program changes the way of working by carrying out ergonomics education in the form of installing low back pain awareness posters, ergonomics training, and exercise in the form of muscle stretching, gymnastics will significantly reduce complaints of acute low back pain in 
the intervention group mechanic workers. compared to the control group mechanic workers who only carried out an intervention program in the form of installing low back pain awareness posters.

(Larinier, Balaguier and Vuillerme, 2020) said that ergonomic training and exercise in the form of muscle stretching, gymnastics would significantly reduce complaints of acute low back pain in the intervention group mechanic workers compared to the control group mechanic workers who only carried out an intervention program in the form of installing low back pain awareness posters. This can occur because the effect of the interventions carried out is long-term, to prevent LBP complaints from disappearing from occurring for 12 months, so that the assessment was more accurate by knowing the complaints of LBP in the last 12 months, while for acute LBP complaints in the last seven days it is strongly influenced also with the workload in the last seven days where it is known that sampling was carried out in a pandemic situation. Workload during the last seven days was reduced in almost all work locations including intervention and control group work sites.

The results of data analysis on the proportion category of chronic LBP complaints about the intervention group showed a decrease from $68.6 \%$ to $45.7 \%$ and in the control group from $57.1 \%$ it increased to $80 \%$, significantly in the chronic LBP proportion category for the intervention group and control found a significant difference with a p-value of 0.003 , where the intervention was proven to reduce complaints of chronic LBP by $43 \%$. Referring to these results, the second hypothesis is proven that the intervention program changes the way of working by carrying out ergonomics education in the form of installing low back pain awareness posters, ergonomics training, and exercise in the form of muscle stretching, gymnastics will significantly reduce complaints of low back pain in the intervention group mechanic workers compared to workers. the control group mechanic who only carried out an intervention program in the form of installing low back pain awareness posters.

This can happen because the effect of the intervention in the form of ergonomic training is carried out where there is a change in the way of work as evidenced by Umami (Umami and Hartanti, Ragil Ismi, 2014). The mechanical workers who work in a squatting position, hunched over $>1$ hour and lift heavy objects $>20 \mathrm{~kg}$ manually decreased quite high compared to baseline data, The effect of the intervention was also seen where there were significant differences in the two groups for the length of time working in the squatting and hunched positions. Other interventions carried out are in the form of exercise by stretching muscles $1 \mathrm{x} /$ day and exercising once per month which can increase spinal muscle strength and improve blood circulation in the spinal area so that it can prevent LBP complaints from occurring within the last 12 months, referring to (Hasan, Ismail, and Raja Azidin, 2010). Physiologically, this activity can increase brain blood flow, especially to the spine and joints, strengthen the back muscles, increase the body's flexibility change in brain neurotransmitters (eg norepinephrine, endorphins, and serotonin) and develop structural changes in the body. brain. Meanwhile, in the psychological aspect, it can increase feelings of control, feelings of competence and self-confidence, relieve stress and depression as well as an opportunity to feel happier and feel more enjoyable.

These results are consistent with the reference in a study conducted by (Steffens et al., 2016) which states that intervention in the form of a combination of exercise and education carried out for up to one year can reduce LBP complaints by $45 \%$ with RR 0.55 (0.41- 0.74$)$. In a study conducted by (Huang et al., 2020) Exercise alone and exercise combined with education both prevent episodes of low back pain and 
related absenteeism, also concluded that the combination of exercise and education is the most effective method of preventing LBP.

The results of data analysis in the category of changes in acute LBP complaints in the intervention group found that $60 \%$ of complaints improved and in the control group as many as $45.7 \%$ of complaints were improved of acute LBP complaints improved in the higher intervention group could be an effect of the intervention carried out even though the significance was obtained a non-significant difference with a $\mathrm{p}$-value of 0.231 where the intervention was not proven to change acute LBP complaints in both groups, as was the case previously discussed, this could be related to sampling carried out during the pandemic where the workload was reduced during the last seven days at the work location of the intervention and control groups.

In the category of changes in chronic LBP complaints in the intervention group, it was found that $25.7 \%$ of complaints improved, and in the control group, as much as $11.4 \%$ of complaints improved of chronic LBP complaints improved in the higher intervention group could be an effect of the intervention carried out although significant differences were not found. Significant with a p-value of 0.124 so that the intervention was not proven to change chronic LBP complaints.

This is different from the results of the previous analysis related to the proportion of chronic LBP complaints where the intervention was proven to significantly reduce the number of mechanical workers with chronic LBP complaints. This can occur because of the lack of strict supervision carried out on research subjects, so that improvements that can be made are to consider regular interviews, for example, once every three months to research subjects to ensure that the intervention program runs well by closely monitoring especially mechanical workers with complaints of LBP. Pre- intervention is to run the intervention program that has been determined.

In the analysis above, the results were not significant in several categories such as manual handling acute LBP complaints, changes in acute and chronic LBP complaints. Several things need to be considered to improve the intervention program to get better results, namely by implementing additional program interventions, according to (Slovak, 2012) said the most important ergonomic intervention programs are to reduce workplace exposures, by doing engineering in the form of changes in the workplace design, changes in work processes and replacement or adjustment of tools used by workers. In this recent study, researchers intervened to change the way of working by doing ergonomics training to avoid awkward postures at work, namely squatting and hunched over positions, while other interventions such as changes in workplace design, replacement or adjustment of tools needed in the workplace have not been carried out.

Some limitations that were difficult to overcome by researchers related to the COVID-19 pandemic situation is that interviews cannot be conducted directly at the worksite, so this method is replaced with interviews through Microsoft teams, WhatsApp, and telephone applications that are sometimes constrained by networks or signals. Another limitation is that in this study to find out LBP complaints only use questionnaires with yes or no answers and are not equipped with more complete tools.

\section{CONCLUSION}

Intervention program on how to work by conducting ergonomics education in the form of installing low back pain awareness posters and ergonomics training found significant differences in changes the ways of working for the length of work in squatting position, bending position in the intervention group compared to the control group, and no significant differences in 
manual handling activities in the two groups.

\section{REFERENCE}

Bertani, Alessandro, Di Paola, Gioacchino Russo, Emanuele Tuzzolino, Fabio. (2018) 'How to describe bivariate data', Journal of Thoracic Disease, 10(2), pp. 1133-1137. doi: 10.21037/jtd.2018.01.134.

Bridger, R. (2018) Introduction to Ergonomic Design. 11th edn, Application of Systemic-Structural Activity Theory to Design and Training. 11th edn. London and New York: Routledge.

Directorate of Occupational Health and Sports, M. of $\mathrm{H}$. of the R. of I. (2018) Konsensus Tatalakasana Penyakit Akibat Kerja. 1st edn. Edited by PERDOKI. Jakarta: Kementrian Keseheatan Republik Indonesia.

Hasan, H., Ismail, H. and Raja Azidin, R. M. F. (2010) 'Preventive methods of low back pain', CSSR 2010 2010 International Conference on Science and Social Research, (September 2019), pp. 1278-1282. doi: 10.1109/CSSR.2010.5773733.

Huang, Rongzhong Ning, Jie Chuter, Vivienne H. Taylor, Jeffrey Bruce Christophe, Demoulin Meng, Zengdong $\mathrm{Xu}, \mathrm{Yu}$ Jiang, Lihong. (2020) 'Exercise alone and exercise combined with education both prevent episodes of low back pain and related absenteeism: Systematic review and network meta-analysis of randomised controlled trials (RCTs) aimed at preventing back pain', British Journal of Sports Medicine, 54(13), pp. 766-770. doi: 10.1136/bjsports-2018-100035.

Jin, Wencheng Han, Qinghong Fu, Xingran Wan, Juan. (2011) 'Anchorage system for FRP material-based sheets', Huazhong Keji Daxue Xuebao (Ziran Kexue Ban)/Journal of Huazhong University of Science and Technology (Natural Science Edition), 39(8).

Koh, David Aw, Tar-Ching Aw, Tar Ching Koh, David Thompson, John P. (2017) 'Diagnosis and Management of Occupational Diseases', Textbook of Occupational Medicine Practice, (November), pp. 64-69.

Landau Sabine, E. B. S. (2001) A Handbook of Statistical Analyses Using Stata, Technometrics. London: Chapman \&Hall/CRC.

Larinier, N., Balaguier, R. and Vuillerme, N. (2020) 'How much do we know about the effectiveness of warm-up intervention on work related musculoskeletal disorders, physical and psychosocial functions: Protocol for a systematic review', BMJ Open, 10(11), pp. 1-8. doi: 10.1136/bmjopen-2020-039063.

Li, G. and Buckle, P. (1998) 'Practical method for the assessment of workrelated musculoskeletal risks Quick Exposure Check (QEC)', Proceedings of the Human Factors and Ergonomics Society, 2(November), pp. 1351-1355. doi: 10.1177/154193129804201905.

Machliss, S. B.-O. and B. (2011) Applied Anatomy \& Physiology of Yoga. England: Yoga Synergy Pty Ltd.

Ministry of Health Republic of Indonesia (2016) 'Peraturan Menteri Kesehatan Republik Indonesia Nomor 56 Tahun 2016 Tentang Penyelenggaraan Pelayanan Penyakit Akibat Kerja', Menteri Kesehatan, pp. 1-35.

Morris, P. E. (2013) 'Prevention of occupational diseases Purpose', Encyclopedia of Sports Management and Marketing, 13(March).

Rahayu, W. (2012) 'Faktor-faktor yang Berhubungan dengan Keluhan Muskuloskeletal pada Pekerja Angkat-angkut Industri Pemecahan Batu di Kecamatan Karangnongko 
Kabupaten Klaten', Jurnal Kesehatan Masyarakat Universitas Diponegoro, 1(2), p. 18728.

Slovak, A. (2012) 'Occupational and Environmental Health: Recognizing and Preventing Disease and Injury', Occupational Medicine, 62(3), pp. 230-230. doi: 10.1093/occmed/kqr102.

Steffens, Daniel Maher, Chris G. Pereira, Leani S.M. Stevens, Matthew L. Oliveira, Vinicius C. Chapple, Meredith Teixeira-Salmela, Luci F. Hancock, Mark J.. (2016) 'Prevention of lowback pain a systematic review and metaAnalysis', JAMA Internal Medicine, 176(2), pp. 199-208. doi: 10.1001/jamainternmed.2015.7431.

Sulaeman, Y. A. and Kunaefi, T. D. (2015) 'LOW BACK PAIN (LBP) PADA PEKERJA DI DIVISI MINUMAN TRADISIONAL (Studi Kasus CV. Cihanjuang Inti Teknik)', Jurnal Tehnik Lingkungan, 21(2), pp. 201211. doi: 10.5614/jtl.2015.21.2.10.

Suma'mur (2009) Higiene perusahaan dan kesehatan kerja. Jakarta: Sagung Seto.

Trippolini, Maurizio Alen Janssen, Svenja Hilfiker, Roger Oesch, Peter. (2018) 'Measurement Properties of the Modified Spinal Function Sort (MSFS): Is It Reliable and Valid in Workers with Chronic Musculoskeletal Pain?', Journal of Occupational Rehabilitation, 28(2), pp. 322-331. doi: 10.1007/s10926017-9717-y.

Umami, A. R. and Hartanti, Ragil Ismi, A. D. P. (2014) 'Hubungan antara Karakteristik Responden dan Sikap Kerja Duduk dengan Keluhan Nyeri Punggung Bawah (Low Back Pain) Pada Pekerja Batik Tulis (The Relationship Among Respondent Characteristic and Awkward Posture with Low Back Pain in Batik Workers)', Pustaka Kesehatan, 2(1), pp. 72-78.
Week, C. T. (2016) 'Health Education and Behavior; New Health Education and Behavior Findings from San Diego State University Reported ( A Process Evaluation of an Efficacious Family-Based Intervention to Promote Healthy Eating: The Entre Familia: Reflejos de Salud Study', 42(5), pp. 5-7.

Widanarko, Baiduri Legg, Stephen Devereux, Jason Stevenson, Mark. (2015) 'Interaction between physical and psychosocial risk factors on the presence of neck/shoulder symptoms and its consequences', Ergonomics, 58(9), pp. 1507-1518. doi: 10.1080/00140139.2015.1019936. 